\title{
Legend Collections in European Literature of the Mid 19th Century
}

\author{
Natalia A.Tuliakova* \\ National Research University \\ Higher School of Economics \\ St.-Petersburg, Russian Federation
}

Received 14.02.2016, received in revised form 14.07.2016, accepted 10.08.2016

\begin{abstract}
In the present paper, I analyze peculiarities of legend collections in European literature of the mid 19th century, taking into consideration their Swiss, Spanish and Belgian variants. Starting with the history of the legend in European literature, I compare three volumes of legends - Sieben Legenden by Keller, Leyendas by Bécquer, Légendes flamandes by De Coster. What is being dwelt upon are their attitude to the source (pretext), conflict, composition, setting, personage type. The conclusion is made that the three collections are similar in their authors' understanding of the legend, which is presented as a tale that depicts a conflict between a person and some established set of values. In Sieben Legenden this set of values is given as most natural for people and despised by the official religion. The protagonists go through a series of trials to return to the harmonious family. In Leyendas the established order is mainly embodied into an old tradition or superstition, which the protagonist tries to ignore, with a fatal outcome. In Légendes flamandes the protagonist may disregard some ethical or moral concepts, only to happily understand their mistake later on. Though all the books appeared in the time of the late Romanticism in non-dominant European cultures, they present different sides of Romantic philosophy: romantic irony (Keller), love to the supernatural (Bécquer), attitude to history (De Coster).
\end{abstract}

Keywords: literary legend, legend collections, Gottfried Keller, Charles de Coster, Gustavo Adolfo Bécquer.

Research area: philology.

Citation: Tuliakova N.A. (2016) Legend collections in european literature of the mid 19th century. J. Sib. Fed. Univ. Humanit. Soc. Sci., 15(4), 504-514. DOI: 10.17516/1997-1370-0032

(C) Siberian Federal University. All rights reserved

* Corresponding author E-mail address: n tuljakova@mail.ru 


\section{The early European legend}

In the late $18^{\text {th }}$-early $19^{\text {th }}$ century German Romantics took a deep interest in folk songs and poems, and subsequently developed fascination with folk legends as well, which was partly explained by Jacob Grimm in his article Gedanken: wie sich die Sagen zur Poesie und Geschichte verhalten (Thoughts: How Poetic Tales Correlate with History, 1808). The first stage of integrating the legend into literature was collecting and adapting folk texts. To name just a few of the numerous examples, I will mention Volksmärchen der Deutschen (German Folk Tales, 1782-86) with Legenden vom Rübezahl (Rübezahl Legends) by Johann Karl August Musäus and Volks-Sagen, Märchen und Legenden (Folk Tradition, Tales and Legends, 1812) by Johann Gustav Büsching.

At the same time poets and writers were enchanted with religious legends, with their purity and high moral values which were highly appreciated in this historically and politically uneasy time: "Romanticism went into ecstasies over their childish tone and their believing spirit, as it had done over folk-songs and chap-books" (Meyer x). Friedrich Schlegel accounted for the necessity to renew the genre and chose some texts for re-editing. In 1820, Dom heiliger Sänger, oder fromme Gesänge der Vorzeit (Saint Songs, or Pious Hymns of the Olden Time) with Schlegel's Foreword were published in Vienna and Prague, followed in 1830 by Legenden, fromme Sagen und Erzählungen (Legends, Pious Tales and Stories) published with the help of Johann Peter Silbert.

The attention to the legend was not confined to Germany only. Almost every country showed a certain interest in such tales, especially in their national variants. Gathering legends was followed by their synthetic interpretation and transforming their plots to create new works of art. For instance, the well-know story of the Mouse-Tower on the Rhine was interpreted by Southey (God's Judgement on a Wicked Bishop, 1799), Zhukovsky (Sud Bozhij nad jepiskopom / Divine Justice over the Bishop, 1831) and Hugo (Légende du mauvais archevêue / Legend of the Evil Archbishop, 1842); Flaubert based his masterpiece, La Légende de Saint Julien l'Hospitalier (The Leg- end of Saint Julian the Hospitaller, 1857), on the famous saint's biography.

Not unnaturally, there appeared absolutely original legends not related to folklore, as elements in bigger narratives (Scott incorporated a legend into the centre of his novel The Legend of Montrose, 1819), or as complete stories (A Legend of the Rhine by Thackeray, 1845). Still, many authors took advantage of the legends' presupposed 'source' and claimed to have borrowed them from the lore.

In this way, European literature witnessed the appearance of the legend as a literary genre, in which folk features were masterfully combined with religious issues. Nevertheless, the legend, just like the fairy-tale, can be considered a newly-formed genre of literature. Being comparatively new, it continued to develop throughout the $19^{\text {th }}$ century and underwent certain changes. It is obvious that both the time of creation and the national culture can account for the predominant formal elements and peculiarities of the legend.

\section{Further development}

The late $19^{\text {th }}$ century is characterized by the tendency to unite legends into cycles or collections, where the author's idea was expressed in a more vivid way. Such collections comprise all legend subtypes - purely religious legends (Gottfried Keller, Selma Lagerlöf), folk legends (Gustavo Bécquer, Dmitrij Mamin-Sibiriak), or synthesis of these forms (Charles De Coster, Anatole France). On the one hand, uniting legends can be considered a legacy of gathering folk-tales. However, such collections differ from the collected stories of the early $19^{\text {th }}$ century, as they often demonstrate a development of the author's message.

\section{Keller}

Keller's cycle Sieben Legenden (Seven Legends) was first published in 1854. It is a common truth that the Swiss writer borrowed the plots from Ludwig Gotthard Theobul Kosegarten's two-volume book of hagiographic Legenden (Legends, 1804). Kosegarten, a German poet, interpreter, and Lutheran preach, in his Legenden retold some biographies of the early Middle Ages saints. Keller's book includes Eu- 
genia, Die Jungfrau und der Teufel (The Virgin and the Devil), Die Jungfrau als Ritter (The Virgin as Knight), Die Jungfrau und die Nonne (The Virgin and the Nun), Der schlimm-heilige Vitalis (The Naughty Saint Vitalis), Dorotheas Blumenkörbchen (Dorothea's Flower-Basket), Das Tanzlegendchen (A Legend of the Dance).

Keller uses the word legende in its purely religious meaning, which can be disclosed as the life of a saint (Jolles 39). With the only exception of the story of saint Vitalis, the collection contains tales of women who, one way or another, turned to Christianity. "No doubt their primary purpose was edification; but at the same time psychological interest in the famous saints had to be gratified and mere human curiosity was eager to hear tales of wonder. Very special interest was turned to 'conversion,' that inward process which transforms a dweller in the 'world' into a citizen of the heavenly city" (Meyer ix). Keller's stylization was so perfect that even his translator, Charles Handschin, thought the "naïve ingenuousness, poetic charm, and quaint humor" of the Sieben Legenden to be the main author's objectives (Handschin 5).

However, Keller shifts from the pious position typical of Kosegarten. The conversion to Christianity is paradoxically seen not as a virtue but as a type of seduction. "The legends are a seven-fold variation on one theme which makes one statement, saying the same thing each time in an altered situation. The figures in the legends are victims of an unusually unnatural form of seduction perpetrated by organized religion. They are led to confuse the roles of heavenly and earthly, of unnatural and natural behaviour, and they make decisions based on false appearances" (Frank 129). Although quite humorous and ironical, the legends reveal quite a lot of drama from the very beginning. The movement towards the tragedy is not obvious since Keller only displays it slightly in the first legend, as an afterword to the story with a happy end. Eugenia, who chose to hide herself as brother Eugenius in a convent, understood that love was the essence of life, managed to marry the handsome Aquilinus happily and convert her husband to Christianity as well. The fact that her faith made her a martyr is mentioned only casually and in a form which does not catch the reader's attention:

The legend goes on to relate how the whole family returned to Rome about the time when that enemy of the Christians, Valerian, came to the throne, and how, during the persecutions which then broke out, Eugenia added to her fame that of a famous heroine of the faith and martyr, and then only made full manifestation of her great strength of soul $^{1}$ (Keller 1911: 24).

The word 'death' is never even pronounced.

The following three legends are centered round the image of the Virgin Mary, who helps two women in difficulties. In Die Jungfrau und der Teufel, when Bertrade is sold by her husband Gebizo to the Devil, the Virgin Mary struggles with the Archenemy and defeats him. In Die Jungfrau als Ritter, when the widowed Bertrade's new admirer turns out too infantile and timid, the Blessed Virgin takes his shape and participates in the tournament instead of him to win Bertrade's hand. In Die Jungfrau und die Nonne, when the beautiful nun Beatrix secretly wishes to live a life of a wife and a mother for some time, Mary takes her place in the convent while Beatrix seeks for happiness.

The attitude towards Christianity in these three tales is already controversial. On the one hand, the opposition between the good and the evil, as well as the victory of the former, is expressed through Christian values. On the other hand, Christians do not always fight for the good - the figure of the devout but cruel Gebizo speaks for itself. Futhermore, Mary, the embodiment of the good, is depicted as an ordinary woman, with some faults and weaknesses and an obvious sympathy towards all lovers. "The saints in Keller's legends show their virtues best when they get to the cozy bourgeois surrounding, with their domestic values being of the highest importance" (Kleiner 6). Be-

\footnotetext{
1 Die Legende erzählt nun weiter, wie die gange Familie nach Rom zuruckkerte, um die Zeit, da der christenfeindliche Valerianus zur Regierung gelangte, und wie nur während der ausbrechenden Verfolgungen Eugenia noch eine berühmte Glaubensheldi und Märtyrerin wurde, die erst jetzt ihre große recht bewies (Keller 1919: 17).
} 
sides, the life in the convent and the gifts that the nuns bring to the Virgin Mary are appreciated by Her less than what is a woman's best gift - children. Beatrix's eight sons are a bigger miracle than all the nuns' embroidery.

These three central legends are the least tragic in the cycle, but they establish the values which are most natural for people: love, family, children. "It is clear that Keller turned Kosegarten's legends advocating Christian asceticism into celebrations of the fullness and beauty of life on earth" (Frank 129). However, the church tends to deprive people of these values or regards them as sinful.

The next legend, Der schlimm-heilige Vitalis, declares the church's failure to distinguish between the virtue and the sin. The Alexandrian monk Vitalis helps lost women to abandon their profession and leads "them back to virtue." However, his conduct, as it requires spending much time with the lost women, is repelled by the official church, which does not comprehend the essence of things and announces the monk a sinner. In the end Vitalis has to leave the convent, but he finds happiness with a young woman Iole who thinks herself a little more cunning than the Virgin Mary:

All of a sudden she resolved that if the Virgin Mary had not sense enough to lead the erring monk back to more respectable ways, she would undertake the task herself, and lend the Virgin a hand in the business, little dreaming that she was the unwitting instrument of the Queen of Heaven, who had now begun to intervene ${ }^{2}$ (Keller 1911: 72-73).

Iole pretends to be a prostitute to get a chance to see Vitalis frequently and enamour him, after which he is expelled from the convent and marries her. This all actually proves to have been the plan of the Blessed Mary.

The last two legends of the cycle more vividly imply the narrator's grief over the suf-

\footnotetext{
2 Plötzlich enschloß sie sich, wenn die Jungfrau Maria nicht so viel Verstand habe, aus einen wohlanständigeren Weg zu führen, dies selbst zu übernehmen und ihr etwas ins Handwerk zu pfuschen, nicht ahnend, das die selbst das unbewußte Werkzeug der bereits einschreitenden Himmels-Köningin war (Keller 1919: 56).
}

ferings of the converted women and over the absurdity of their sacrifices. The tortured and killed Christian Dorothea sends her lover, Theophilus, a basket with apples and flowers from Heaven, as a proof of Paradise existence. It turns him to Christianity, and he perishes too. The descriptions of tortures and death have nothing in common with the first legend, $E u$ genia. Here the author does not find a reason to smile or tell a joke. The Virgin Mary keeps silence and never interferes. Even after death, in Heaven, Dorothea and Theophilus cannot be together: they are separated, go astray and

...once in blissful forgetfulness they ventured too near the crystal habitation of the Holy Trinity, and entered within. There they lost all consciousness, and like twins beneath a mother's heart they fell on sleep, and no doubt are sleeping still, unless meantime they have been able to make their way out ${ }^{3}$ (Keller 1911: 97).

Paradise is depicted as a place with no harmony and justice.

In the last legend, Tanzlegendchen, the little Musa has a vision in church: King David, accompanied by angels, dances with her to give her an idea of Heavenly bliss. She abandons dancing, and with it all the music and joy of life, only to die three years later and finally get to Heaven. Here Keller at last depicts Paradise, which appears to be rigid, narrow-minded and ungrateful. When Musa'a namesakes, the nine Greek Muses, who are once a year invited to a feast in Heaven, sing to thank for the hospitality, their singing reminds everybody of the earthly beauty so poignantly that Paradise inhabitants cry and moan in pain, and the nine Muses are expelled from Paradise for good.

Although the legends have many common features - the setting, the type of personage, the pretext, the conflict - the perception of the reader moves from the idea of the Christian world as a happy one, where a person can be

\footnotetext{
3 einst gerieten sie in holdesten Vergessen zu nahe an das kristallene Haus der heiligen Dreifaltigkeit und gingen hinein; dort verging ihnen das Bewußtsein, inden sie, gleich Zwillingen under dem Herzen ihrer Mutter entschliesen und wahrscheindlich noch schlafen, wenn sie inzwischen nicht wieder haben hinauskommen können (Keller 1919: 78).
} 
miraculously saved from any danger, to the merciless reality of separation, suffering and death. Keller never explicitly expresses his true attitude to the conversion of the women, but the increasing tension of the book outweighs its pious intonation.

\section{Bécquer}

At the end of the 1850s-beginning of the 1860s Bécquer published many legends in the journal El Contemporáneo, later uniting them into a large volume of Leyendas (Legends). Unlike Keller's collection, the legends of Bécquer's cycle do not show any evolution and have a certain, stable genre invariant, which deals with the issues of temptation, sin (crime) and retribution. Partly, the writer's aim was reviving the Spanish past - in the architecture, which he admired, and in the oral word, which, to his mind, could soon be lost.

The book comprises about 30 small texts, the most famous of which are La cruz del Diablo (The Devil's Cross), La corza blanca (The White Doe), La promesa (The Promise), El monte de las ánimas (The Spirits' Mountain), Maese Pérez, el organista (Master Pires), Los ojos verdes (The Emerald Eyes), La ajorca de oro (The Golden Bracelet), La cueva de la Mora (The Cave of the Moor's Daughter), El Miserere, El rayo de luna (The Ray of Moonshine). What seems important here in comparison with Keller's cycle is the expression of the Romantic nationalism. The legends are very similar to folk ones, centering round a personage who cannot resist some kind of temptation. Keller exploits hagiographic Roman plots, whereas Bécquer deals only with the Spanish folk-art.

The author collected the legends while visiting different parts of Spain during his short lifetime - Soria, the Moncayo, Toledo, and others. In each case, Bécquer indicates the legend's origin within Spain, thus referring to some old tradition of the oral word. Moreover, in many texts he explicitly names the person who told him the story and the circumstance of the narration. Still, the Spanish writer uses the pretexts differently from Keller. While the plot of Sieben Legenden exploited hagiography viewed by a person with a different set of values, Bécquer puts traditional folk plots into the ethical-religious context. He adheres to the plots of famous fairy tales and transforms them to some extent, quite frequently integrating religious motives into the literary text. For instance, Los ojos verdes is a variation of Lorelei tales, La corza blanca is a version of a tale of a supernatural (enchanted) spouse, $L a$ promesa - of a dead spouse. The folk tradition is revealed in the system of motives (warning and its violation), whereas the religious influence can be observed in the system of images (church, cross, monk, icon), in the general message - the ethical-moral intention which demands following the Christian set of values, subjugation to authority, inevitability of requital.

Unlike Keller's ironic legends, Bécquer's stories are devoid of any comic or humoristic overtones, they are painted with gloomy, dramatic, tragic hues. Katherine Lee Bates, one of the first Bécquer's translators into English, called them "strange, romantic, and wild" (Bates 5). They deal with the relationship between a person and some established set of values which he dares struggle with, the collision always leading to re-establishing the old tradition. The emphasis is placed on the emotional side of the stories as their outcome is usually predictable. "The subject-matter of these legends is various, it is frequently borrowed from folk tales, but the tragic conflict, which determines the plot development, in almost all the cases is based on the craving for unattainable, eluding and covered with a mysterious veil" (Plavskin 459).

Built according to a similar pattern, Leyendas are often framed with a foreword or/ and afterword, in which the narrator tells how he got to a place connected with some superstition or tradition, or became involved with a peculiar thing or phenomenon (the Devil's cross, a mysterious voice, printed music with strange words) and after that received some explanation of the point of interest from a local inhabitant.

The legends are centered round a prohibition, superstition, warning (written or oral, explicit or implicit), its breech and the subsequent retribution. In La corza blanca the main 
personage, huntsman Garcés, attracted by the mystery of the white doe, ignores all the warnings, catches the doe and shoots her, mistaking her for the devil. The doe is in fact his beloved, the beautiful Constanza. The handsome Pedro from La ajorca de oro commits sacriledge when his lover Maria asks him to steal the golden bracelet from the wrist of the Virgin Mary statue in Toledo cathedral. When he comes to the cathedral at night, the statues there come alive and he goes mad. The legend Los ojos verdes tells about the brave lord Fernando who crosses the forbidden line in the forest while hunting and meets a woman with green eyes who traps him into the stream to drown.

The offender in all the legends is a male character, though a woman's role is quite important. She tempts a man's courage, pity, compassion, or pride. The narrator does not always give a comment on her fate, but from time to time he hints at the demonic origin of a woman and her beauty. In other cases a man breaks his promise given to a woman or the prohibition imposed by her; then the woman perishes.

The dangerous - be it a place, person, or object - involves mystery and attracts the heroes, though they know about the impending catastrophe. The warning can be given in the form of rumor, gossip, tradition; the prohibition can be imposed as a promise or oath of the hero, or be implied by the Biblical or moral commandment. The violation is the outcome of the person's desire to know the unknown, to possess the forbidden, to reach beyond the visible. They quite often subconsciously mention the devil, like Garcés in the following passage:

\footnotetext{
"What the devil," he exclaimed, rousing himself from the state of uncertainty into which he had fallen. "Greater harm than that which has overtaken me cannot come to pass and if, on the other hand, what Esteban has told us is true, oh, then, how sweet will be the taste of my triumph!"4 (Becquer 1909 : 117)
}

\footnotetext{
4 “-iQué diantre! - exclamó saliendo del estado de incertidumbre en que se encontraba: - mayor mal del que me ha sucedido no puede sucederme, y si por el contrario es verdad lo que nos ha contado Esteban... ¡oh, entonces, cómo he de saborear mi triunfo!" (Bécquer 1912: 81)
}

The outcome of the legend is always tragic - the personage's death or insanity.

He reached the place at last, but on arriving there, his hair stood erect with horror, the words throbbed vainly in his throat and he had to clutch the trunk of a tree to save himself from falling to the ground ${ }^{5}$ (Bécquer 1909: 125).

The result of the event described in the legend is the mysterious evidence that caught the narrator's attention. This frightening or mystic evidence can be some material object or just a vague impression; the legend can even lack it, in which case the final sounds as abrupt, tense, cut short. In some legends the frame tells about the evidence of the miracle, and it also contains a warning against some of the narrator's actions. For example, the narrator must not take off his hat in front of the Devil's cross or pray near it. The forbidden place is also the Moor's cave. This prohibition is imposed by someone whose knowledge is deeper than that of the narrator - it is the legend-teller, the person who keeps and shares the oral tradition.

The time in Leyendas, although it is rarely specified, can be defined as crossing of two temporal layers - Bécquer's contemporaneity, the $19^{\text {th }}$ century in the frame, and the dark Middle Ages in the main body of the legends. This fusion shows how the past lives in the present - in the form of legends or objects that accumulate memory of the time gone. Time strata coexistence is intensified with the help of an embedded narrative (a-legend-within-a-legend), usually connected with events that led to the prohibition against approaching some place. The salient example is El monte de las ánimas, where Alonso explains why nobody should come near the mountain on All Saints' Eve. The legend tells not about a single event that finishes with the narrative but of a recurrent action that takes place in eternity rather than in some specific time. In some cases Bécquer

\footnotetext{
5 Llegó al fin; pero al llegar, sus cabellos se erizaron de horror, las palabras se anudaron en su garganta, y tuvo que agarrarse al tronco de un árbol para no caer á tierra (Bécquer 1912: 90).
} 
deliberately avoids any indications of time, creating most typical images and situations.

The daily time in the tales corresponds with the folk and religious ideas of temporality, which accounts for the choice of time for the climax event. In all cases it is the nighttime. In folklore night is identified with the time of the devil whose power is almost absolute until the break of dawn; the Christian tradition links night to death, which precedes the morning resurrection, so it is also the most dangerous time of day. When the lasses ask Uncle Gregorio what can happen at night at the summit of the Moncayo (El Gnomo), he explains:

In its deep and dark caverns, on its wild and lonely summits, in its hollow heart there live certain diabolical spirits that, during the night, pour down its cascades in swarms and people the empty spaces, thronging like ants upon the plain, leaping from rock to rock, sporting in the waters and swinging on the bare boughs of the trees ${ }^{6}$ (Bécquer 1909: 198).

The local specificity in Leyendas is revealed not only in the attribution given in the subtitle but also in the plot. The place of violating the prohibition is presented by two types sacred and accursed. The former is connected with religious sacraments (a church, a cathedral, the cave where the moor was christened). However, this is not a place where the hero can be saved, rather where his guilt can be mitigated or, on the contrary, where the deadliness of his sin is emphasized.

The latter - the accursed or evil place - is connected with the semantics of the border, it is usually a stream or a mountain. In folklore this kind of place is regarded as an alien place which is perilous for human beings. Sometimes it is embodied in the oxymoron form of an accursed sacred place, like the Devil's cross, the expression which repels the narrator with its incongruity.

\footnotetext{
6 En sus profundas simas, en sus cumbres solitarias y ásperas, en su hueco seno, viven unos espíritas diabólicos que durante la noche bajan por sus vertientes como un enjambre, y pueblan el vacío, y hormiguean en la llanura, y saltan de roca en roca, juegan entre las aguas ó se mecen en las desnudas ramas de los árboles (Bécquer 1912: 129).
}

The legends are peculiar due to the uniqueness of the narrator's viewpoint. On the one hand, he stresses his intention to follow the original narration, claiming that he does not introduce any changes or add any literary embellisments. On the other hand, the choice of lexical and grammatical units characterizes his style as very steady, thus his speech can hardly be a retelling close to the original. There occasionally occur explicit declarations of the fictitious nature of the story, although it has a subtitle which states its origin. Placed into the context of the cycle, the legends with two messages - verisimilitude and fictitiousness create an ambiguous atmosphere, where each event can be regarded as true and fantastic, as real and as seeming.

\section{De Coster}

The harmonious fusion of the folk and hagiographical traditions can be observed in De Coster's cycle Légendes flamandes (Flemish Legends). It was the author's first attempt, followed by Contes brabançons (Tales from Brabant, 1861), to create a collection of narratives in the traditional style. Comprising the tales written during the previous two years (1856-57), Légendes flamandes were published at the end of the 1857, but dated as 1858. The collection consists of four legends, which are quite different in form and exploit different patterns - those of fablio, hagiography, ballad and fairy tale. De Coster combines the humorous attitude to religious issues with the tension of historical approach. He places his, mainly comic, personages deep into the social and historic context, but he also uses features of folk comic genres to lessen the dramatic effect.

The first legend, Les Freres de la bonne trogne (The Brotherhood of the Cheerful Countenance), demonstrates the conflict between the pagan and the Christian attitudes. The male population of the settlement Uccle establish the Brotherhood of the Cheerful Countenance, with Bacchus as their idol, in order not to make him furious. They gather, drink beer and behave like heathens. When Uccle is endangered by the Irontooth brigand, the drunken men cannot protect their native settlement, but the "good wives of Uccle," with the help of the 
Virgin Mary, do the men's job. Afterwards the men's society is abolished, and the new one is instituted - The Order of the Women-Archers of Uccle, under the protection of the Virgin Mary.

The next legend, Blanche, Claire et Candide (The Three Sisters), relates the story of the three beautiful sisters who abandon the secular society and travel far from Rome on magic palfreys to avoid the bothersome attention of their young suitors. When their horses halt at Haeckendover, in Brabant, the sisters decide to build a church in God's honour. Two times they select the wrong place, not believing that God could have chosen this insignificant settlement. Finally, they are indicated the right place, and in the end the church is built with God's help.

Though following the rules of the hagiographic genre, De Coster depicts the sisters and their conduct as quite silly and vain, and the naivety of the girls makes the reader smile. Their actions are by no means kind or generous - in fact, being young, healthy, beautiful and rich, they constantly complain to God and say ridiculous prayers:

\begin{abstract}
"Ah, dear beloved, rather let us pass our lives old, ugly, leprous, and then descend into purgatory, among devils, flame, and brimstone, there to wait until you deem us pure enough at length to take us into your Paradise, where we shall be allowed to see you and love you for ever. Have pity upon us. Amen"' (De Coster, 1920: 35).
\end{abstract}

Sire Halewyn (Sir Halewyn), based on vampire stories, is the most obscure of the four legends. The ugly and ruthless Sir Halewyn gives his soul to the devil in exchange for the beautiful voice, with which he entices young virgins, murders them and takes out their hearts so as to obtain youth, strength and beauty. No male can ever kill him. After his slaying the sixteenth girl, Anne-Mie, the daughter

\footnotetext{
7 "Ah! Plutôt, doux aimé, faites-noun toutte cette vie passer étant vieilles, laides, lépreuses, puis en enfer descendre au milieu des diables, flammes et souffre, pour là attendre que vous nous jugiez pures assez et enfin nous recevoir en votre Paradis, où il nous sera permis vous contempler et aimer éternellement. Ayez de nous pitié. Amen" (De Coster 1980: 42)
}

of Sir Reul, Magtelt, defies the villain. She is lead by God and with her has the Sword of the Lion brought from the Crusade by her father. Magtelt easily defeats Halewyn, cutting off his head and taking it home to display as a sign of her victory. All the dead girls go to Heaven, and Halewyn's stone heart is kicked by everybody.

The basis for this legend is the old ballad (Ulinger) unfolded into a long stylized text. Its prototype is obviously the story of Judith and Holoferne, with the culmination point in the scoundrel's decapitation. This plot is often used in balladry, in which case a text is defined as a religious ballad (Entwistle 59). The Belgian writer also added the story of the Prince of the Stones which evidently takes its roots in the fairy-tales of the Romanticism.

Smetse Smee tells about a poor desperate blacksmith Smetse who sells his soul to the devil to get seven years of prosperity and happiness. Kind and generous, he helps all the poor, and when the Holy Family occur near his house, he is very hospitable to them despite his failure to recognize them. He is rewarded with three gifts - to seize the power over those who climb his plum-tree, who sit in his chair, and who get into his sack. The smith does not dare confess his sin to Saint Joseph, therefore he has to ask for such equivocal ways to save himself. When the devil comes to demand his soul, Smetse escapes the danger by trapping and beating him. Twice the devil gives him two more periods of freedom, but when he arrives for the third time, the cunning smith is determined to cancel the contract and succeeds. When he dies, he is admitted to heaven for being cruel to the devil, Jesus Christ appreciating it more than being good-hearted and merry. The last legend, just like the first one, exploits the pattern of the fablio and the tale (Trousson 89), but on a higher level, involving the historic background. In Smetse Smee, history is most vivid: the devil appears in the figures of the three historic personages, Flandre's worst enemies, Catholic Jacob Hessels, Duke of Alba and Philip II of Spain.

Unlike the two foregoing cycles, the conflict between the good and the evil in De Coster's book varies, and Légendes flamandes are manifold in shaping it. The type of the col- 
lision is determined by the genre pattern reconsidered by the author. The analysis of the folk and literary traditions within the book speaks for its being a single cycle and not just a collection of separate stories (like Bécquer's Leyendas). Stylistic devices that De Coster uses to integrate the borrowed folk material into the literary text are the same throughout the book, these being either a folk plot in a romantic form, or a romantic plot in a folk form.

There are several sources for each legend, mainly related to the Middle Ages, Renaissance or Romantic cultures, which all have close associations with folk art. In this respect Légendes flamandes inherit the Romanticism attitude to a national culture, language and history. The book is written in the French language of the $16^{\text {th }}$ century. Its first translator into English, Harold Taylor, admits: "I believe that no more perfect example of a pastiche exists in the language" (Taylor 10). Another effect produced by such language is arousing associations with the $16^{\text {th }}$ century Flemish painting (Mallinson, 16; Hanse, 308).

The structure of each legend depends on the collision between two mainstream traditions within the legend. They mainly represent two points of view, or sets of values, or attitudes. In the first legend it is the clash between a fairy tale and hagiography, in the second between hagiography and chivalric novels, in the third - between a ballad and a fairy tale, in the fourth - between a fablio and a fairy tale. The evil itself is embodied in different shapes: the imaginary, pagan devil Bacchus and cruel robbers in The Brotherhood, a too vague temptation which the sisters resist in The Three Sisters, an outcast protected by the devil in Sire Halewyn, and the inquisitors in Smetse Smee. The outcome is always the victory of the goodin this respect De Coster's cycle is much more optimistic than Keller's and Bécquer's ones.

As all the narratives depict the struggle between the good and the evil represented through the person's choice between God and the devil, the cycle unfolds a universal plot. Still, the thematic similarity of the legends is leveled by their stylistic and genre differences. The four tales offer multifarious variants of displaying the conflict. Each following legend partly uses the preceding ones and raises the collision onto the further level as compared with the motives used in the previous legends. Thus De Coster moves from the commonplace conception of the evil as disobeying the church directives to the historic interpretation of the evil as betrayal of moral values, compatriots, native land. Retribution is seen as punishment by pain (both in life and after death) in the beginning, but finally is understood as the eternal curse by the descendants. The first, naïve type of attitude is typical of Blanche, Claire and Candide, of the men of Uccle, the latter - of Smetse Smee. The intermediary stage, the religious one, still devoid of many historic connotations, is represented in Sire Halewyn.

This shift in developing the main concepts of Légendes flamandes creates the effect of moving and reconsidering the old traditions. Thus it can be stated that the book has its own, metatextual plot - interaction of different genre and styles. It is emphasized by numerous examples of self-citations and self-allusions allowing the reader to look at each situation in the context of another tradition. That is how the author ascribes the same plot to many genres of folklore, literature and culture - the place and the way of a person in the world history, which is the earthly embodiment and repetition of the Holy history.

This history is centered round the most important sets of events - temptation, treachery, punishment and atonement. The Holy history is still being done, Saint Joseph and Saint Mary are still on their way to Egypt, Jesus Christ resorts to Smetse's assistance. It is a human being who punishes Halewyn for his haughtiness, viciousness and murders, who chastises Flandre's enemies for their numerous crimes. Smetse combines all the previous types of reaction towards the evil: he is naïve and earnest at the same time. When he "bursts out with that stream of invective and monstrous mockery" (Taylor 11), his merciless accusations of the Duke Alba and Philip II are inconsistent with his ideas of Paradise where he will be eating a rice pie with a silver spoon.

What allows De Coster to call his stories légendes is the Christian subject-matter. All the stories depict how the Biblical history, which 
can never end, is reflected in people's lives. There is a miracle - an integral part of the legend - in all tales, but its nature is different and is directly connected with the historicism of the narrative. In Les Freres de la bonne trogne the miracle influences people's lives (saves the community). The legend Blanche, Claire et Candide involves the miracle which has a more private nature and helps the sisters to get rid of the admirers and then build a church, so it does not have a universally relevant character. In Sire Halewyn the miracle is impossible without the personal participation of Magtelt, who is selected by God as His instrument. Smetse Smee intertwines Smetse's life with the Holy history: Saint Joseph's miracle saves the protagonist's soul, while his initiative in beating Flandre's enemies helps God to struggle with the devil and punish the evil.

\section{Conclusion}

The three collections of legends, which appeared in the mid $19^{\text {th }}$ century, definitely belong to the non-dominant European cultures to the Swiss, Spanish and Belgian, which in this time were still preoccupied with the Ro- mantic tendencies. These books emphasize different aspects of Romanticism and reveal its multifacedness, being very unlike in their intonation, choice of the subject-matter, and the attitude. Keller's Sieben Legenden actively exploit the concept of Romantic irony and its interest in the natural, opposite to the artificial and dogmatic. Bécquer's Leyendas reflect the obsession of the Romanticism with the supernatural. De Coster creates a complicated historiographic concept developing the Romanticism's concern with the relations between history and legend.

Nevertheless, all the collections have important common features. Being all based on some older, respected tradition, they establish its authority - both through referring to it and through the outcome of the legends' conflict. The universal pattern of the plot may be summarized in the following way: a personage (whether a protagonist or an antagonist) tries to break some tradition (expressed in various forms), the attempt in majority of cases proving to be a failure. Thus the genre of the legend reveals the stability of contents accompanied with the variety of form.

\section{References}

Bates, Catherine Lee. Preface in Bécquer, Gustavo Adolfo. Romantic Legends of Spain. Trans. by Cornelia Frances Bates and Catherine Lee Bates. New York: Thomas Y. Crowell \& Company, 1909, pp. v-vi.

Bécquer, Gustavo Adolfo. Obras escogidas. Madrid: Librería de Fernando Fé; Sevilla: Librería de Antonio Fé, 1912. 353 p.

Bécquer, Gustavo Adolfo. Romantic Legends of Spain. Trans. by Cornelia Frances Bates and Catherine Lee Bates. New York: Thomas Y. Crowell \& Company, 1909. 271 p.

De Coster, Charles. Légendes flamandes: Texte intégral. Geneve, Paris: Slatkine, 1980. 204 p.

De Coster, Charles. Flemish Legends. Trans. by Taylor Harold. New York: Stokes, 1920. 171 p.

Entwistle, William J. European Balladry. Oxford: The Claredon Press, 1939. 404 p.

Frank, Barbara R. 1974. Irony in Keller's Sieben Legenden The Germanic Review: Literature, Culture, Theory. Volume 49, Issue 2, pp. 129-145.

Handschin, Charles H. Foreword in Keller, Gottfried. Legends of Long Ago. Trans. by Charles H. Handschin. Chicago: The Abbey company, 1911, pp. 3-5.

Hanse, Jose. Histoire illustrée des lettres françaises de Belgique. Bruxelles: La Renaissance du livre, 1958. $658 \mathrm{p}$.

Jolles, André. Einfache Formen. Halle: Max Niemeyere Verlag, 1930. 272 p.

Keller, Gottfried. Gesammelte Werke. Band 5. Studdgart: Gottaschen Buchhandlung; Berlin: Klemm, 1919. $462 \mathrm{~s}$.

Keller, Gottfried. Seven Legends. Trans. by Martin Wyness. Glasgow: Gowans and Gray, Ltd., 1911. 112 p. Kleiner, S. Gottfried Keller in Keller, Gottfried. Sem' legend (Seven Legends). Per. T. Bernshtein i S. Kleinera. Moscow: Pol'za, 1911, pp. 3-9. 
Mallinson, Vernon. Modern Belgian Literature (1930-1960). London: Heinemann, 1966. 205 p.

Meyer, Richard M. Introduction in Keller, Gottfried. Seven Legends. Trans. by Martin Wyness. Glasgow: Gowans and Gray, Ltd., 1911, pp. viii-xii.

Taylor, Harold. Translator's Note in De Coster, Charles. Flemish Legends. Trans. by Taylor Harold. New York: Stokes, 1920, pp. ix-xi.

Trousson, Raymond. Charles De Coster ou La vie est un songe. Biographie. Bruxelles: Labor, 1990. $237 \mathrm{p}$.

Plasvskin, Zakhar. Ispanskaya literatura (Spanish Literature) in Istoriya vsemirnoj literatury (History of World Literature). Pod red. I.A. Bernshteina. Moscow: Nuka, 1991. Vol. 7, ss. 458-463.

\title{
Циклы литературных легенд в европейской литературе середины XIX века
}

\author{
Н.А. Тулякова \\ Национальный исследовательский университет \\ Выстая школа экономики \\ Российская Федерация, Санкт-Петербург
}

\begin{abstract}
Аннотация. В статье анализируются особенности циклов легенд в европейской литературе середины XIX века на примере швейцарского, испанского и бельгийского вариантов. После краткого обзора истории возникновения легенды как жанра в европейской литературе сопоставляются три цикла - «Семь легенд» Киллера, «Легенды» Беккера, «Фламандские легенды» де Костера. Рассматриваются соотношение текста и фольклорного / агиографического претекста, конфликт, хронотоп, композиция, тип персонажа. Сделан вывод о том, что для всех трех циклов характерно одинаковое понимание жанра как рассказа о столкновении личности и установленной системы ценностей. В «Семи легендах» эта система естественна для людей, но осуждается христианством. Протагонист проходит через ряд испытаний, чтобы вернуться к семейным ценностям. В «Легендах» установленный порядок представлен в форме суеверия, на которое протагонист не обращает внимания, что приводит к трагическим последствиям. Во «Фламандских легендах» протагонист нарушает моральную или этическую заповедь, но счастливо избегает наказания, осознав свою ошибку. Циклы, созданные в эпоху позднего романтизма в малых европейских литературах, представляют собой различные аспекты романтической философии: романтическую иронию (Келлер), тягу к сверхъестественному (Беккер), отношение к истории (де Костер).
\end{abstract}

Ключевые слова: литературная легенда, циклы легенд, Г. Келлер, Ш. де Костер, Г. А. Беккер.

Научная специальность: 10.00 .00 - филологические науки. 